\title{
CORN SILAGE, META-ANALYSIS OF THE QUALITY AND YIELD OF DIFFERENT REGIONS IN THE WORLD
}

\author{
Isidro García-Chávez ${ }^{1,2}$, Edgar Meraz-Romero ${ }^{1,3}$, Octavio Castelán-Ortega ${ }^{1,4}$, Job Zaragoza- \\ Esparza $^{1,5}$, Jorge Osorio-Avalos ${ }^{4}$, Lizbeth Esmeralda Robles-Jiménez ${ }^{4}$ and Manuel González- \\ Ronquillo ${ }^{1,4, *}$
}

1 Programa de Maestría y Doctorado en Ciencias de la Producción y de la Salud Animal, Facultad de Medicina Veterinaria y Zootecnia, Universidad Nacional Autónoma de México, 04510, México.

2 Facultad de Medicina Veterinaria y Zootecnia, Centro de Enseñanza, Investigación y Extensión en Producción Agrosilvopastoril, Universidad Nacional Autónoma de México. Chapa de Mota, Estado de México. 54350; isigacha@fmvz.unam.mx (I.G.C.);

3 Facultad de Medicina Veterinaria y Zootecnia, Centro de Enseñanza, Investigación y Extensión en Producción Animal en Altiplano, Universidad Nacional Autónoma de México. Tequisquiapan, Querétaro. 76790; emerazr@yahoo.com.mx (E. M.R.)

4 Facultad de Medicina Veterinaria y Zootecnia, Departamento de Producción Animal, Universidad Autónoma del Estado de México, México. Instituto Literario 100. Toluca, Estado de México. 50000; oacastelano@uaemex.mx (O. C.O.); josorioa@uaemex.mx (J. O.-A.); lizroblez@hotmail.com (L. E. R.J.); mrg@uaemex.mx(MGR)

5 Facultad de Estudios Superiores Cuautitlán, Ingeniería Agrícola, Universidad Nacional Autónoma de México. Carr. Cuautitlán-Teoloyucan Km 2.5. San Sebastián Xhala, Cuautitlán Izcalli, Estado de México. 54750; jzaragozaseccionprod@gmail.com (J. Z.-E.)

* Correspondence: mrg@uaemex.mx

\begin{abstract}
Corn silage (Zea mays L.) is the most widely used energy resource in the diets of dairy cattle around the world; it stands out for its higher biomass yields, good palatability, homogeneous quality at harvest and ease of silage due to its higher soluble sugar content. It was carried out a search of studies related to dry matter yield (ton ha-1), population density (plant density ha-1), dry matter (DM), crude protein (CP), neutral detergent fiber (NDF), non-fibrous carbohydrates (NFC), organic matter $(\mathrm{OM})$, DM digestibility (DMD) and neutral detergent fiber digestibility (NDFD) and milk production per hectare $(\mathrm{kg}$ of milk ha-1) that was determined using MILK2006®. It was carried out a cluster analysis (CL, PROC CLUSTER) obtaining six groups of corn silage: CL1: "Starch", which included DMD, DFDN, TDN1xDM, Mega calories per kg of DM and kg of milk/ton/DM; CL2: "Fats" which included TDN1xMS, Mcal/kg/DM and kg of milk/ton/DM; CL3: "Dry Matter", conformed only by DFDN; CL4: "Plant Density" including Yield of DM ha-1 and Milk Production ha-1 ${ }^{-1}$ CL5: "Neutral Detergent Fiber" and CL6: "Raw Protein". It is concluded that CL1 was characterized by a higher DMD, DFND, CNF and starch that allow a higher TNDx1DM and an energy concentration $(\mathrm{Mcal} / \mathrm{kg} / \mathrm{DM})$ that shows a higher milk production $\left(\mathrm{kg}\right.$ of milk/ton $\left./ \mathrm{DM} \mathrm{ha}^{-1}\right)$. The characteristics of CL2 with higher EE, allow a higher TNDx1DM and an energy concentration (Mcal $/ \mathrm{kg} / \mathrm{DM})$ with a higher milk production ( $\mathrm{kg}$ of milk/ton/DM ha-1).
\end{abstract}

Keywords: Corn silage 1, meta-analysis 2, milk production 3, cluster 4

\section{Introduction}


Corn silage (Zea mays L.) is the most widely used energy resource in the diets of dairy cattle worldwide [1], this energy comes from the starch in the grain fraction [2], which is the main source of metabolizable energy in corn silage and has been considered an important characteristic [3] . Corn silage stands out for its higher biomass yields, good palatability [ $\underline{4}, \underline{5}]$, homogeneous quality at harvest and ease of silage due to the higher soluble sugar content [ $\underline{6}]$ with respect to other grasses. It is important to mention that parameters such as crude protein (CP), neutral detergent fiber (NDF) and neutral detergent fiber digestibility (NDFD) [7] should be considered, as well as fast growth and resistance to foliar diseases [묘, $]$, characteristics related to the ideal idiotype of forage corn [10] $]$.

The corn crop has a constant yield, in a wide variety of environmental and agronomic conditions [3]; although the nutritional quality depends on many factors, such as genotype, plant density, growth conditions, maturity and humidity of the crop at harvest []. The increase of forage productivity in dry matter (DM), without decreasing the quality, is a determining factor for an efficient milk production [11]. Currently the hybrids commercialized, were formed for grain production and have been put on the market for their biomass production, without considering the nutritional quality of DM and its digestibility [ $[$ ]; these qualities allow selecting the varieties, not only to optimize grain production, but also to perfect the potential and forage characteristics [12]. Its value can be improved, with additives, which contribute to the preservation of nutrients and improve the efficiency of feeding [13] , guaranteeing quality by promoting lactic acid fermentation and inhibiting undesirable microorganisms [1ㅜ] .

The MILK2006 ${ }^{\circledR}$ program [15] is an instrument that allows the evaluation of nutritional components of forage and the estimation of milk production per ton of DM. Using a forage energy value predicted from the Detergent Acid Fiber (DAF) content and the potential intake of DM, based on the Neutral Detergent Fiber (NDF) content and digestibility. This milk quality index has become a focal point for silage evaluation [토]

The genetic improvement of forage maize raises the need to identify sources of germplasm and take advantage of the existing genetics[] $]$ identifying varieties with productive capacity and nutritional quality [11]. The objective of this study was to carry out a review of researches on quality and yield of corn silage in different regions in the world, which was analyzed with the program MILK2006® estimating milk production per ton of DM, allowing a characterization of nutritional quality, forage yield and potential milk production of different silages worldwide.

\section{Materials and Methods}

\subsection{Data Collection}

The search that was made was confirmed by the systematic review of studies made on the quality and yield of corn silage fodder in the different regions in the world. The publications were obtained from Google academic, Redalyc, Elsiever, SCOPUS and Web of Science databases. The key words used in the work were: "silage", "corn", "yield", "composition", "chemistry", "nutrient", "value", as well as their combinations and their terms in plural. The total number of scientific articles selected for the meta-analysis was 57: (Akisn and Shaver 2014; Anaya et al., 2009; Bentley, 2009; Bentley, 2010; Bentley, 2011; Byers et al., 1965; Carpintero y Prieto, 1992; Castañeda et al., 2006; Cattani et al., 2017; Darby et al., 2017; Darby, 2010; Darby, 2012; Darby, 2013; Darby, 2015; Darby, 2017; Darby y Lauer, 1998; Di marco et al., 2002; Domínguez et al., 2009; Euken, 2018; Ferraretto et al., 2015; Fonseca et al., 2000; Franco et al., 2016; Gaafar, 2018; Guedes et al., 2012; Hemken et al., 1970; Hernández et al., 2003a; Hernández et al., 2003b; Holt et al., 2016; Inifap, 2014; Lawrence, 2008; Ji et al., 2011; Jiménez-Calderón et al., 2018; Jiménez-Leyva et al., 2016; Lara et al., 2018; Lynch et al., 2013; M.K. O'Neill, 2017; Matielo de Paula et al., 2016; Núñez et al., 2001; Núñez et al., 2003; Núñez et al., 2010; Oshita et al., 2007; Paula et al., 2016; Peña et al., 2006; Peyrat et al., 2016; Reimann-Skonieki et al., 2017; Ruiz et al., 2013; Ruiz et al., 2014; Ruiz et al., 2006; Santos et al., 2010; Sucu et al., 2016; Sykes et al., 2017; Tadeo et al., 2012; Thomas et al., 2001; Virginia, 2017; Valmir, 2013; Weiss y Wyatt 1999; Xu et al., 2015)

\subsection{Inclusion criteria}


For eligibility and inclusion, studies had to present agronomic data and nutritional variables, such as: dry matter yield (tons ha-1), planting density (number of plants ha-1), dry matter (DM), crude protein $(\mathrm{CP})$, neutral detergent fiber (NDF), non-fibrous carbohydrates (NFC), organic matter (OM), dry matter digestibility (DMD) and neutral detergent fiber digestibility (NDFD).

\subsection{Calculations}

Missing data for starch and fat (EE) in those studies that did not contain this information were calculated according to the National Research Council, (NRC) [16]. Net energy for lactation (ELN, $\mathrm{MJ} / \mathrm{kg} / \mathrm{DM}$ ), total digestible nutrients $(\mathrm{TDN})$, kilograms of milk per ton of dry matter (kg milk/ton/DM), and kilograms of milk per hectare ( $\mathrm{kg} \mathrm{milk} \mathrm{ha}^{-1}$ ) were calculated using the MILK2006® program [15]. The estimated value of EE was adjusted to the milk yield according to the fat content of the milk to reflect the concentration of its relative energy, thus reflecting the amount of energy required to produce the estimated amount of milk. In the model, milk production is estimated from a cow with a live weight of $612 \mathrm{~kg}$, fed a diet with $300 \mathrm{~g} / \mathrm{kg}$ of NDF with corn silage as the only forage and production of $35 \mathrm{~g} / \mathrm{kg}$ of milk (kg/day) [15]. The missing values for NDFD were calculated using a regression equation with the data obtained from the registered papers that contained this information:

$$
\mathrm{NDFD}(\mathrm{g} / 100 \mathrm{~g})=77.96( \pm 1.85)+[(\mathrm{g} / 100 \mathrm{gNDF}) *(-0.36( \pm 0.95))], \mathrm{R}^{2}=0.40, \mathrm{n}=144
$$

The estimated milk production was estimated using the MILK2006® model [15]. In the same way, the TDN was estimated.

\subsection{Database}

The database was integrated by 547 sources of information of magazines published and found in the five regions in the world (Africa: $n=4$, Asia: $n=22$, Europe: $n=74$, North America: $n=408$ and South America: $n=39$ ); as well as the sources of information by region of the world and genetic line of the corn (Table 1 ). Fifteen variables related to dry matter production characteristics, planting density and nutritional characteristics were considered (Table 2).

Table 1. Source of maize information by region and genetic line in the world

\begin{tabular}{ccc}
\hline Continent & Type & N \\
\hline African & Hybrid & 4 \\
Asian & Hybrid & 22 \\
Europe & Criollo & 37 \\
Europe & Hybrid & 37 \\
North America & Criollo & 7 \\
North America & GMO & 11 \\
North America & Hybrid & 390 \\
South America & Criollo & 10 \\
South America & Hybrid & 29 \\
\hline Total & & 547
\end{tabular}

Table 2. Variables considered for the study of meta-analysis of corn silage in the world. 


\begin{tabular}{cc}
\hline Abbreviation & Definition \\
\hline DM/Rend/ton ha ${ }^{-1}$ & Dry matter yield in tons per hectare \\
Density ha ${ }^{-1}$ & Density of plants per hectare \\
DM & Quantity of Dry Matter \\
DMD & Dry matter digestibility (dry base) \\
CP & Crude Protein (dry base) \\
FDN & Neutral Detergent Fiber (dry base) \\
NDFD & Neutral Detergent Fiber Digestibility (dry base) \\
NFC & Non-Fibrous Carbohydrates (dry base) \\
OM & Organic matter (dry base) \\
EE & Fat (dry base) \\
Starch & Starch (dry base) \\
TDN1xDM & Total Digestible Nutrients (dry basis) \\
Mcal/Kg/DM & Mega calories per kg of dry matter \\
$\mathrm{Kg} \mathrm{milk} \mathrm{ton} \mathrm{DM}$ & Kg of milk per ton of dry matter \\
Kg/milk ha ${ }^{-1}$ & Milk production (Kg) per ton of dry matter per hectare \\
\hline
\end{tabular}

\subsection{Statistical analysis}

The analysis of the variables was carried out in two independent stages: an analysis of the interrelationships between the 15 variables was carried out (multivariate analysis) and with it to estimate their contribution of the variables on the total variance, applying a factorial analysis (PROC FACTOR, SAS Institute INC., 2007) [17]

The grouping of the information sources in homogeneous levels was carried out through the analysis of hierarchical "Clustering" Ward method (PROC CLUSTER, SAS Institute INC., 2007) [17] using the selected variables. Five hundred and forty-seven observations of corn silage were evaluated, to know which group of variables correlated with each other, obtaining six clusters. According to integrated groups, an ANDEVA was performed between the six levels $(\mathrm{P}<0.05)$. The corn groups were adjusted to similar productive conditions and were determined from the variables considered for this study. To determine the differences between the groups formed (multiple comparisons of means), Tukey's test was used [17]]. Likewise, to determine the degree of relationship between the variables analyzed in this study, a Pearson correlation analysis was performed.

\section{Results}

The 547 observations shown in Table 1 were mostly made up of $82 \%$ of observations from the American continent (75\% North America and 7\% South America) and 13\% from the European continent. These observations met the search requirements shown in Table 2 , which allowed generating the database for the development of the work and its subsequent analysis in the MILK2006® and successively the Clustering Analysis (CL) that resulted in a hierarchical dendrogram (Figure 1), conforming the six CL of components of corn silage

Descriptive statistics for corn silage are shown in Table $\underline{3}$, where the global corn silage yield averages 15.70 tons of DM and an average population density of 76,155 plants per hectare. The average MS is $33.11 \mathrm{~g} / 100 \mathrm{~g}$ DM, with a digestibility of $63.68 \mathrm{~g} / 100 \mathrm{~g} \mathrm{DM}, \mathrm{CP}$ of $7.8 \mathrm{~g} / 100 \mathrm{~g}$ DM and NDF of $49.74 \mathrm{~g} / 100 \mathrm{~g}$ DM with a digestibility of $60.48 \mathrm{~g} / 100 \mathrm{~g}$ DM. While for NFC they range in average from $33.20 \mathrm{~g} / 100 \mathrm{~g}$ DM, with MO of $94.16 \mathrm{~g} / 100 \mathrm{~g}$ DM, with $3.51 \mathrm{~g} / 100 \mathrm{~g}$ DM for EE and 23.39 $\mathrm{g} / 100 \mathrm{~g}$ DM for starch. The average TND is $66.66 \mathrm{~g} / 100 \mathrm{~g}$ DM, with $1.41 \mathrm{Mcal} / \mathrm{kg} / \mathrm{DM}$, producing $531.44 \mathrm{~kg}$ of milk/ton/DM and $19,190.8 \mathrm{~kg}$ of milk ha-1. 
Table 3. Average, standard deviation and minimum and maximum values of the variables analyzed. The chemical composition is expressed in $\mathrm{g} / 100 \mathrm{~g}$ of DM

\begin{tabular}{|c|c|c|}
\hline Variable & Mean \pm DE & Min-Max \\
\hline $\mathrm{DM} /$ Rend/ton ha-1 & $15.7 \pm 8.3$ & $2.75-53.6$ \\
\hline Density ha-1 & $76,155 \pm 15570$ & $50,000-100,000$ \\
\hline $\mathrm{DM}$ & $33.1 \pm 8.4$ & $11.1-61.1$ \\
\hline DMD & $63.6 \pm 11.2$ & $0.0-85.2$ \\
\hline $\mathrm{CP}$ & $7.8 \pm 1.4$ & $4.4-14.9$ \\
\hline $\mathrm{NDF}$ & $49.7 \pm 8.2$ & $31.0-69.9$ \\
\hline NDFD & $60.4 \pm 4.2$ & $29.8-68.8$ \\
\hline NFC & $33.2 \pm 8.6$ & $5.7-59.8$ \\
\hline $\mathrm{OM}$ & $94.1 \pm 1.6$ & $71.6-99.0$ \\
\hline EE & $3.5 \pm 0.7$ & $1.2-6.2$ \\
\hline Starch & $23.3 \pm 8.8$ & $2.0-75.1$ \\
\hline TDN1xDM & $66.6 \pm 4.1$ & $48.3-75.1$ \\
\hline $\mathrm{Mcal} / \mathrm{Kg} / \mathrm{DM}$ & $1.4 \pm 0.1$ & $0.9-1.6$ \\
\hline $\mathrm{Kg} / \mathrm{milk} / \mathrm{ton} \mathrm{DM}$ & $531.4 \pm 55.6$ & $269.4-650.0$ \\
\hline $\mathrm{Kg} / \mathrm{milk} \mathrm{ha}^{-1}$ & $19,190.8 \pm 10217.9$ & $0.0-52540.8$ \\
\hline $\mathbf{N}$ & 547 & \\
\hline \multicolumn{3}{|c|}{$\begin{array}{l}\text { DM/Yield/ton ha }{ }^{-1}=\text { Dry matter yield in tons per hectare, Density ha-1= Plant density per hectare, } \mathrm{DM}=\mathrm{Dry} \\
\text { matter amount, DMD= Dry matter digestibility (dry basis), } \mathrm{CP}=\text { Crude protein (dry basis), NDF= Neutral } \\
\text { detergent fiber (dry basis), NDFD= Neutral detergent fiber digestibility (dry basis), NFC= Non Fibrous } \\
\text { Carbohydrates (dry base), OM= Organic Matter (dry base), EE= Fats (dry base), Starch= Starch (dry base), } \\
\text { TDN1xMS= Total Digestible Nutrients (dry base), Mcal/Kg/DM=Mega calories per Kg of Dry Matter, } \\
\mathrm{Kg} / \text { milk/ton/DM= Milk production (Kg) per ton of Dry Matter per hectare, } \mathrm{Kg} / \mathrm{milk} \mathrm{ha}^{-1}=\mathrm{Kg} \text { of milk per ton of } \\
\text { Dry Matter. }\end{array}$} \\
\hline
\end{tabular}

As it can be observed in Table $\underline{4}$, derived from the analyzed variables and according to their self values (eigenvalue) were conformed the first five factors that explained $81.56 \%$ of the total variance.

Table 4. Auto-values and percentage of explained variance obtained in the factorial analysis for variables analyzed in this study

\begin{tabular}{|c|c|c|c|c|}
\hline Number & Eigenvalue & Percent & Percent & Cum Percent \\
\hline 1 & 5.3870 & 38.5 & & 38.5 \\
\hline 2 & 2.1374 & 15.3 & $=$ & 53.8 \\
\hline 3 & 1.5669 & 11.2 & $=$ & 65.0 \\
\hline 4 & 1.2222 & 8.7 & $=$ & 73.7 \\
\hline 5 & 1.1045 & 7.90 & & 81.6 \\
\hline 6 & 0.8616 & 6.2 & 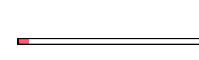 & 87.8 \\
\hline 7 & 0.7089 & 5.1 & & 92.9 \\
\hline 8 & 0.5418 & 3.9 & & 96.8 \\
\hline 9 & 0.2230 & 1.6 & 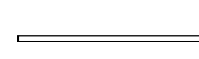 & 98.4 \\
\hline 10 & 0.1509 & 1.1 & & 99.5 \\
\hline 11 & 0.0727 & 0.2 & 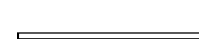 & 99.7 \\
\hline 12 & 0.0221 & 0.2 & 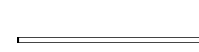 & 99.9 \\
\hline 13 & 0.0009 & 0.05 & 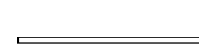 & 100.000 \\
\hline
\end{tabular}




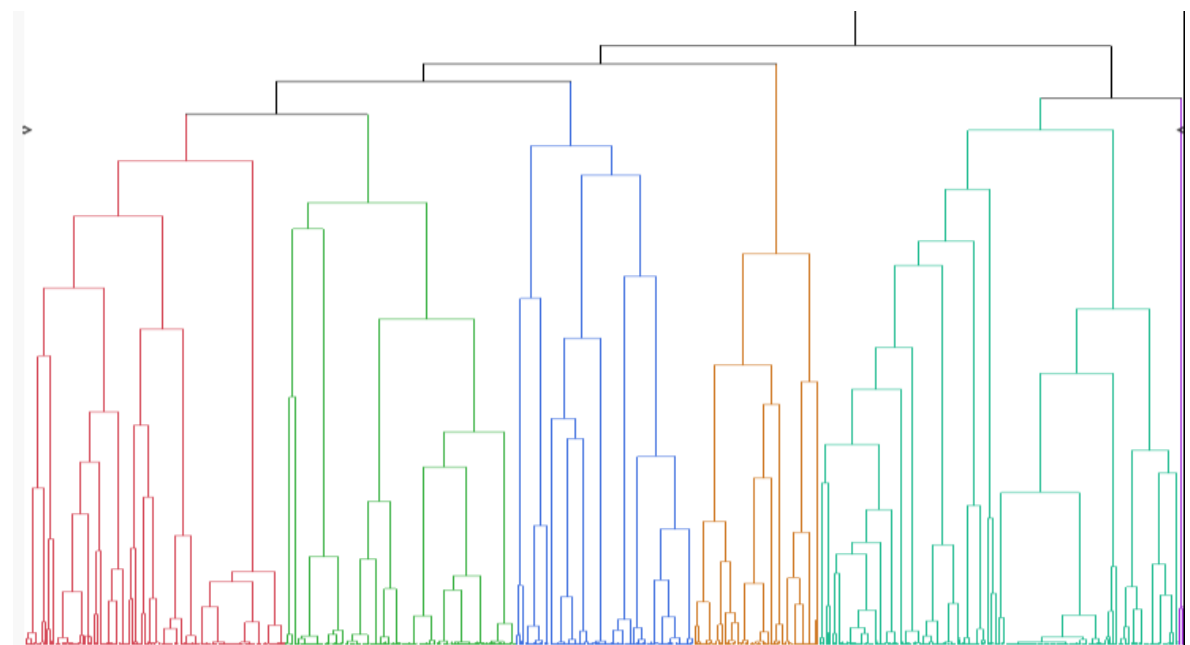

Figure 1. Hierarchical clusters obtained (dendogram) of the cluster analysis from the variables, representing the grouing of the information sources. (CL1) called "Digestibility" (Red), that is because of the variables associated to it was: DMD, CP, NDFD, NEL, and kg/milk/ton DM. The second (CL2), called "Density" (Green), was characterized by corn silage with higher density (number of plants/ha) and NDF\%. In the third (CL3) called "Ash" (Blue) we can find those with the highest ash content, the fourth (CL4) was called "Average" (Orange) because made up of the average of all variables, and the fifth (CL5) was called "Milk yield per ha" (Aqua), which had the highest forage yield (t DM/ha), and $\mathrm{kg}$ milk/ha, and the sixth (CL6) was called "kg Milk/ton" (Purple) had the greater DM, NDF and NEL digestibility (Mcal/kg DM), and kg milk/DM t.

Table $\underline{5}$ shows the integration of the variables for each conformed factor. Factor 1 (F1) represented the highest degree of contribution to total variability (38.5\%), which was integrated by the variables related to total digestible nutrients and Mcal/kg/DM (TDN1xDM and Mcal/kg/DM), as well as the variables NDF, NDFD, NFC and starch. The variables that integrated F2, corresponded to the Digestibility of DM and EE (DMD and EE), integrated by CP, DM and EE, which represented an important $15.3 \%$ of the total variance. The F3, conformed by two variables: production in kilograms of milk per ha and yield in tons DM per ha $\left(\mathrm{kg} / \mathrm{milk} \mathrm{ha}^{-1}\right.$ and DM/Rend/ton ha-1) that corresponds to $11.19 \%$ of the total variance. F4 is made up of only one variable. Neutral Detergent Fiber (NDF) corresponded to $8.7 \%$ of the total variance, and the F5 that corresponds to a variable: Organic Matter $(\mathrm{OM})$ that explained $7.9 \%$ of the total variance.

Table 5. Definition of factors, integration of variables and percentage of total variance contributing to total variance

\begin{tabular}{cccc}
\hline Factor & Variable & Porcentage & $\begin{array}{c}\text { Cumulative } \\
\text { percentage }\end{array}$ \\
\hline F1 & NFC, NDFD, Starch, Kg/milk/ton/DM, & 38.5 & 38.5 \\
F2 & TDN1xDM y Mcal/Kg/DM & 15.3 & 53.8 \\
F3 & CP, DM, DMD y EE & 11.2 & 65.0 \\
F4 & Kg/milk ha ${ }^{-1}$ y DM/Rend/ton ha-1 & 8.7 & 73.7 \\
F5 & NDF & 7.9 & 81.6 \\
\hline
\end{tabular}

$\mathrm{DM} /$ Yield/ton ha-1= Dry matter yield in tons per hectare, DM= Dry matter amount, DMS= Dry matter digestibility (dry basis), $\mathrm{CP}=$ Crude protein (dry basis), NDF= Neutral detergent fiber (dry basis), NDF= Neutral detergent fiber digestibility (dry basis), NFC= Non Fibrous Carbohydrates (dry base), OM= Organic Matter (dry base), EE= Fats (dry base), Starch= Starch (dry base), TDN1xMS= Total Digestible Nutrients (dry base), $\mathrm{Mcal} / \mathrm{Kg} / \mathrm{DM}=$ Mega calories per $\mathrm{Kg}$ of Dry Matter, $\mathrm{Kg} / \mathrm{milk} /$ ton/DM= Milk production (Kg) per ton of Dry Matter per hectare, $\mathrm{Kg} / \mathrm{milk}$ ha-1= Kg of milk per ton of Dry Matt 
According to the correlation analysis, the factors were finally integrated with their respective variables (Table 6 ), conforming six CL: CL1 (123 observations) that we will call "Starch", its associated variables were: DMD, NDFD, TDN1xDM, Mcal $/ \mathrm{kg} / \mathrm{DM}$ and $\mathrm{kg}$ of milk/ton DM. CL2 (109 observations), which we will call "Ethereal Extract", was characterized for containing corn silage variables with the highest TDN1xDM, Mega calories per kg of DM and kg of milk/ton/DM. The CL3 (85 observations) called "Dry Matter" we can find those with the high NDFD content. The LC4 (59 observations) that we will name as "Plant Density" we can find a high Yield of DM ha-1 and higher Production of milk ha-1. The CL5 (169 observations) named as "Neutral Detergent Fiber", which had the highest concentration of NDFD and the CL6 (2 observations) "Raw Protein" with a higher content of CP.

Within the correlations of the analyzed variables shown in Table $\underline{Z}$ it is observed that the yield in tons of DM per ha had a positive correlation $(\mathrm{P}>0.001)$ with the milk yield in $\mathrm{kg}$ per ha $(\mathrm{r}=0.91)$. For NDF we have a negative correlation: NCP $(\mathrm{r}=-0.95)$, starch $(\mathrm{r}=-0.85)$ and with NDF $(\mathrm{r}=.0 .53)$, TDN $(\mathrm{r}=-$ $0.72), \mathrm{Mcal} / \mathrm{kg} / \mathrm{DM}(\mathrm{r}=-0.69)$ and $\mathrm{kg}$ of milk/ton/DM ( $\mathrm{r}=-0.71)$. NDFD has a positive correlation (Pvalue) with NCP ( $\mathrm{r}=0.55)$ and TND ( $\mathrm{r}=0.61)$, with Starch $(\mathrm{r}=0.48)$, and Mcal $/ \mathrm{kg} / \mathrm{DM}(\mathrm{r}=0.42)$ and $\mathrm{kg}$ of milk/ton/DM ( $\mathrm{r}=0.49)$. For NCP, there is a positive correlation with Starch $(\mathrm{r}=0.80)$ and a considerable positive correlation with TND ( $\mathrm{r}=0.67), \mathrm{Mcal} / \mathrm{kg} / \mathrm{DM}(\mathrm{r}=0.63)$ and the $\mathrm{kg}$ of milk/ton/DM ( $\mathrm{r}=0.65)$. For Starch, a positive correlation was observed with TDN ( $\mathrm{r}=0.65), \mathrm{Mcal} / \mathrm{kg} / \mathrm{DM}(\mathrm{r}=0.63)$ and the $\mathrm{kg}$ of milk/ton/DM ( $\mathrm{r}=0.64)$. TDN was positively correlated with $\mathrm{Mcal} / \mathrm{kg} / \mathrm{DM}(\mathrm{r}=0.97)$ and $\mathrm{kg}$ of milk/tonne/DM (r=0.98).

\section{Discussion}

Worldwide, the main corn producers are the United States (USA), China and Brazil[18]; however, its use as a fodder source for cattle feed is carried out in North America, South America and Europe[12]. In Table 1 , we can find a relationship with what Bernades et al. [19], mentioned, where the majority of observations are from North America and Europe, due to the fact that silage production is more developed in temperate zones. While for the observations on the type of corn used we can define two criteria or slopes, the first one is based on the regulation by the legislation in countries of Europe and Asia, of the use of genetically modified crops; the second one is based on the criterion of considering that GMO foods do not differ significantly in production and quality from conventional ones, endorsed by the Food and Drug Administration (FDA), of the USA and that is practiced in America, where $87 \%$ of the GMO surface is planted worldwide [20]

Creole varieties continue to be used for the production of silage because of their high growth rate and resistance to the climate and environment, while hybrids are of small contribution producing little biomass, due to the selection of these varieties for a higher grain yield and not for their biomass yield [].

In Table $\underline{3}$, the influence of maize fodder yield by population density is observed, finding an average value between the highest population density and traditional density [21]; a higher density of plants ha-1 positively affects the production of ton of $\mathrm{DM} \mathrm{ha}^{-1}$, presenting a higher production of Fresh Matter (FM)[22]. Guacapiña et al. [11] found that an increase in planting densities, increases the amount of DM and FM, without modifying the quality (NDF and digestibility) of silage. The optimal cutting moment of corn for silage, was established in a DM content between 30 and $35 \mathrm{~g} / 100 \mathrm{~g} \mathrm{DM}$, both from the productive point of view and the forage quality $[\underline{23}, \underline{24}]$, the average present in silage agrees with the amount of DM in a silage[11], where it is obtained a better nutritional quality and a higher DM yield. A lower amount of DM makes the process more difficult, due to the dilution and dragging of the carbohydrates to the bottom of the silo. On the contrary, a large amount of DM causes difficulty in compacting and the retained air causes heating in the silage material and losses in its quality [24]. Guyader et al. [25] indicated that silage material with high humidity $(<28 \mathrm{~g} / 100 \mathrm{~g}$ DM) will cause increased filtration in the silo and reduce DM intake, while material that is too dry $(>40$ $\mathrm{g} / 100 \mathrm{~g} \mathrm{DM}$ ) is difficult to compact and the oxygen present will produce poor fermentation in the silo. 
Table 6. Analysis of variance (least squared means and standard error) and Tukey's test for the variables studied after integrating the 6 clusters

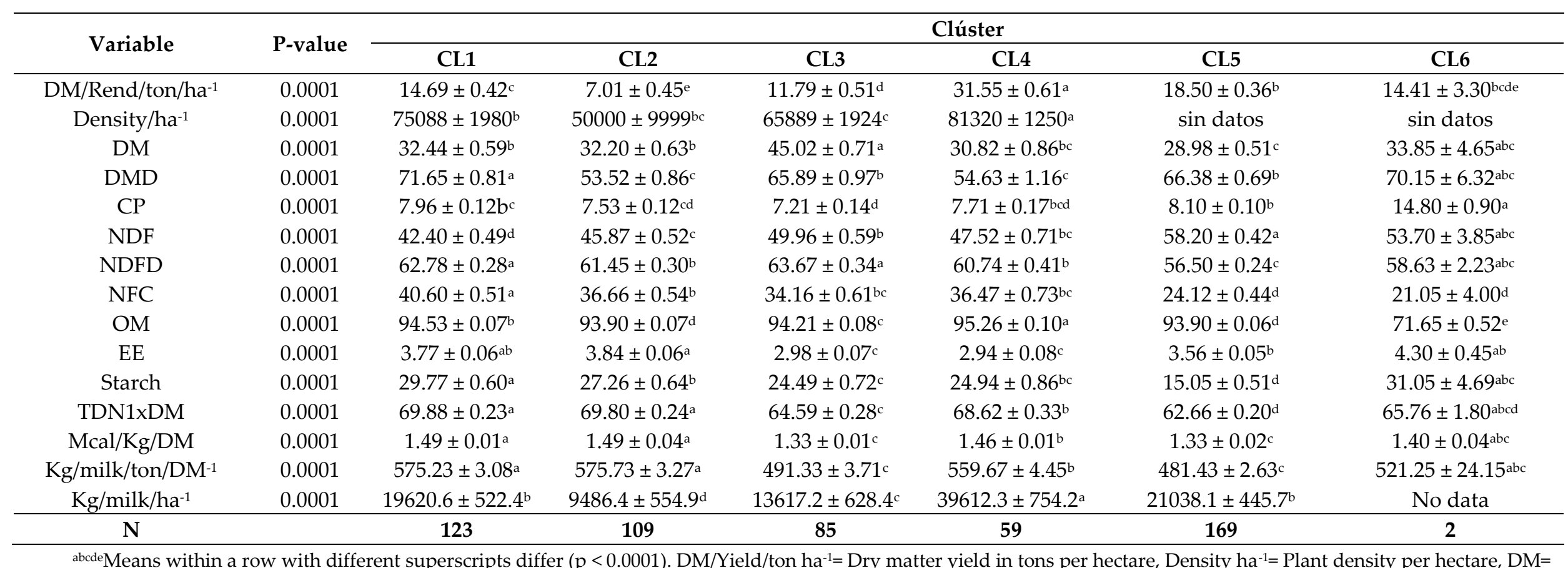

Dry matter amount, $\mathrm{DMD}=$ Dry matter digestibility (dry basis), $\mathrm{CP}=$ Crude protein (dry basis), NDF= Neutral detergent fiber (dry basis), NDF= Neutral detergent fiber digestibility (dry basis), NFC= Non Fibrous Carbohydrates (dry base), OM= Organic Matter (dry base), EE= Fats (dry base), Starch= Starch (dry base), TDN1xDM= Total Digestible Nutrients (dry base), Mcal/Kg/DM=Mega calories per Kg of Dry Matter, $\mathrm{Kg} / \mathrm{milk} / \mathrm{ton} / \mathrm{DM}=$ Milk production $(\mathrm{Kg})$ per ton of Dry Matter per hectare, $\mathrm{Kg} / \mathrm{milk}^{-1}=\mathrm{Kg}$ of milk per ton of Dry Matter. 
Table 7. Correlation analysis of the variables, related with chemical composition of corn silages and milk yield

\begin{tabular}{|c|c|c|c|c|c|c|c|c|c|c|c|c|c|c|}
\hline & $\begin{array}{c}\mathrm{DM} / \text { Rend/ } \\
\text { ton/ha-1 }\end{array}$ & DM & DMD & $\mathbf{C P}$ & NDF & NDFD & NFC & OM & EE & Starch & $\begin{array}{c}\text { TDN1x } \\
\text { DM }\end{array}$ & $\begin{array}{c}\mathrm{Mcal} / \mathrm{Kg} / \\
\mathrm{DM}\end{array}$ & $\begin{array}{c}\mathrm{Kg} / \mathrm{milk} / \\
\text { ton/DM }\end{array}$ & $\begin{array}{c}\mathrm{Kg} / \mathrm{milk} \\
\text { ha-1 }^{-1}\end{array}$ \\
\hline DM/Rend/ton ha-1 & & -0.0879 & -0.0797 & -0.0470 & 0.2431 & -0.1771 & -0.1898 & 0.1383 & -0.2223 & -0.2650 & -0.1859 & -0.1655 & -0.1737 & 0.9067 \\
\hline DM & -0.0879 & & 0.0959 & -0.0875 & -0.1741 & 0.4070 & 0.1804 & 0.0148 & -0.0097 & 0.3389 & 0.0444 & -0.0703 & -0.0332 & -0.0918 \\
\hline DMD & -0.0797 & 0.0959 & & 0.0543 & -0.0557 & 0.0594 & 0.0196 & -0.1229 & 0.0612 & 0.0292 & -0.1376 & -0.1656 & -0.1541 & -0.1076 \\
\hline $\mathrm{CP}$ & -0.0470 & -0.0875 & 0.0543 & & -0.0036 & -0.0190 & -0.1674 & -0.2846 & -0.0119 & 0.0012 & 0.0871 & 0.1076 & 0.1016 & -0.0504 \\
\hline NDF & 0.2431 & -0.1741 & -0.0557 & -0.0036 & & -0.5374 & -0.9553 & -0.0406 & -0.0698 & -0.8512 & -0.7258 & -0.6978 & -0.7157 & 0.1182 \\
\hline NDFD & & 0.4070 & 0.0594 & -0.0190 & -0.5374 & & 0.5541 & 0.0808 & -0.3644 & 0.4875 & 0.6128 & 0.4218 & 0.4943 & -0.0899 \\
\hline NFC & -0.1898 & 0.1804 & 0.0196 & -0.1674 & -0.9553 & 0.5541 & & 0.1408 & -0.0266 & 0.8024 & 0.6761 & 0.6348 & 0.6569 & -0.0693 \\
\hline OM & 0.1383 & 0.0148 & -0.1229 & -0.2846 & -0.0406 & 0.0808 & 0.1408 & & -0.1347 & 0.0186 & 0.1318 & 0.1265 & 0.1285 & 0.2563 \\
\hline EE & -0.2223 & -0.0097 & 0.0612 & -0.0119 & -0.0698 & -0.3644 & -0.0266 & -0.1347 & & 0.2006 & 0.0298 & 0.1418 & 0.1030 & -0.1907 \\
\hline Starch & -0.2650 & 0.3389 & 0.0292 & 0.0012 & -0.8512 & 0.4875 & 0.8024 & 0.0186 & 0.2006 & & 0.6578 & 0.6308 & 0.6476 & -0.1609 \\
\hline TDN1xDM & -0.1859 & 0.0444 & -0.1376 & 0.0871 & -0.7258 & 0.6128 & 0.6761 & 0.1318 & 0.0298 & 0.6578 & & 0.9739 & 0.9888 & -0.0216 \\
\hline Mcal/Kg/DM & -0.1655 & -0.0703 & -0.1656 & 0.1076 & -0.6978 & 0.4218 & 0.6348 & 0.1265 & 0.1418 & 0.6308 & 0.9739 & & 0.9967 & -0.0014 \\
\hline $\mathrm{Kg} / \mathrm{milk} /$ ton/DM & -0.1737 & -0.0332 & -0.1541 & 0.1016 & -0.7157 & 0.4943 & 0.6569 & 0.1285 & 0.1030 & 0.6476 & 0.9888 & 0.9967 & & -0.0087 \\
\hline Kg/milk ha-1 & 0.9067 & -0.0918 & -0.1076 & -0.0504 & 0.1182 & -0.0899 & -0.0693 & 0.2563 & -0.1907 & -0.1609 & -0.0216 & -0.0014 & -0.0087 & \\
\hline
\end{tabular}

$\mathrm{DM} /$ Yield/ton ha ${ }^{-1}=$ Dry matter yield in tons per hectare, $\mathrm{DM}=$ Dry matter amount, DMS= Dry matter digestibility (dry basis), $\mathrm{CP}=\mathrm{Crude}$ protein $(\mathrm{dry}$ basis), NDF= Neutral detergent fiber (dry basis), NDF= Neutral detergent fiber digestibility (dry basis), $\mathrm{CNF}=\mathrm{Non}$ Fibrous Carbohydrates (dry base), MO= Organic Matter (dry base), EE= Fats (dry base), Starch= Starch (dry base), TDN1xMS= Total Digestible Nutrients (dry base), Mcal/Kg/MS=Mega calories per Kg of Dry Matter, $\mathrm{Kg} / \mathrm{milk} / \mathrm{ton} / \mathrm{MS}=$ Milk production $(\mathrm{Kg})$ per ton of Dry Matter per hectare, $\mathrm{Kg} / \mathrm{milk} \mathrm{ha}^{-1}=\mathrm{Kg}$ of milk per ton of Dry Matter. 
The DMD of a high quality forage is around $70 \mathrm{~g} / 100 \mathrm{~g}$ DM of in vitro DM digestibility [26]; the DMD in the present study, is below the parameters described in the meta-analysis of Ferraretto and Shaver [27] from 66.3 to $69.1 \mathrm{~g} / 100 \mathrm{~g} \mathrm{DM}$, but within the range, from 52 to $68 \mathrm{~g} / 100 \mathrm{~g} \mathrm{DM}$, described by Chaudhary et al. [28]. This may be related to an increase in the harvest stage, at advanced maturity, decreases the in vitro digestibility of DM [루] . The CP concentration is between 8 to $11 \mathrm{~g} / 100 \mathrm{~g} \mathrm{DM}$ [28], placing the average value below the established range, although the protein content can vary between 5.2 and $7.5 \mathrm{~g} / 100 \mathrm{~g}$ DM, considering that for a good forage the CP should be higher $7 \mathrm{~g} / 100$ g DM [ [6].

The NDF reported by Calsamiglia et al. [23] is between 44.9 and $57.0 \mathrm{~g} / 100 \mathrm{~g} \mathrm{DM}$, where the average value of silage is within this range, taking into account that a good quality forage has a NDF less than $50 \mathrm{~g} / 100 \mathrm{~g}$ DM []. While NDF digestibility (NDFD) is higher than that described by Ferraretto and Shaver [27] with a content of 42.4 to $48.9 \mathrm{~g} / 100 \mathrm{~g}$ DM. However, although a higher NDFD is desirable, it can reduce the digestibility of starch through an increase in the rate of passage of starch in the gastrointestinal tract [30]. Increased NDFD is associated with feeding behavior and increased DM intake (DMI) [31]. The NFC content is between 27 to $32 \mathrm{~g} / 100 \mathrm{~g} \mathrm{DM}$, allowing a good fermentation [24]; the average NFC in the meta-analysis is higher than $30 \mathrm{~g} / 100 \mathrm{~g} \mathrm{DM}$, characteristic of a good quality forage []. The OM is below the values mentioned by Calsamiglia et al. [23] (95.82 to $95.82 \mathrm{~g} / 100 \mathrm{~g} \mathrm{DM})$, representing a higher concentration of ashes, which in turn produces a decrease in NCP, therefore, a decrease in NDT values [30]. The EE content is between 3.76 and $4.54 \mathrm{~g} / 100 \mathrm{~g}$ $\mathrm{DM}$, being below this range the average value of EE in this study, this result may be due to the fact that the starch in the grain, was gradually increasing, affecting the EE content in mature stages [32].

The starch content is between 10.3 and $34.2 \mathrm{~g} / 100 \mathrm{~g}$ DM, where the average value is within the range, but below the established for the DM amount (in 25 to $35 \mathrm{~g} / 100 \mathrm{~g} \mathrm{DM}$ ), which should contain from 28.0 to $31.8 \mathrm{~g} / 100 \mathrm{~g}$ DM of starch; age of harvest influences starch content, as well as sowing date and/or population density [33]; as grains move towards advanced maturity, starch content increases [25]; however, the vitreous endosperm of the kernel also increases, generating grain hardness and these dry grains are less susceptible to breakage during processing [프] .

The range of TND is between 55 and $78 \mathrm{~g} / 100 \mathrm{~g}$ DM [2], where we can see that the average value of this component is within the range. It is necessary to take into account the negative effects of the harvest, in advanced stages of maturity they damage the utilization of the grain, with a reduction of the TND with more than $40 \mathrm{~g} / 100 \mathrm{~g}$ DM described by Ferraretto and Shaver [27]. The energy value is dependent on the amount of NFC and starch, as well as the NDFD, which give a value of milk per ton of DM and milk per surface [35]. The milk yield increases with the advance of maturity, reaching an optimal level for corn silage with DM contents of 30-40 g/100 g DM []].

In Table $\underline{4} \underline{5}$ and Figure $\underline{1}$ we can note that $\mathrm{F} 1$ explains most of the total variance of the present study, in which the index of milk quality per ton of DM for corn silage, using an energy value derived from summative equations [16] and the DMI predicted from the NDF content and as a basis for the NDF; using a maintenance summative energy equation TDN from NRC [16] for corn silage, including starch and non-starch NFC with a starch digestibility coefficient; the energy value NEL-3x is derived from maintenance TDN, using the empirical equation from NRC [36]. Starch is the main source of metabolizable energy in corn silage, and traditionally it has been considered the most important characteristic of corn silage []]; it represents approximately half of the energy value of the whole plant [16]; fiber is also an essential component of diets, providing 20 to $25 \mathrm{~g} / 100 \mathrm{~g}$ DM of energy from digested fiber []]. Improved utilization of starch and NDFD can increase milk production [37]. Whole plant corn silages typically contain $30 \mathrm{~g} / 100 \mathrm{~g}$ DM of starch and $40 \mathrm{~g} / 100 \mathrm{~g}$ DM of NDF; an increase in starch or NDF can result in higher lactation performance by dairy cows [이]. NDFD favors higher DMI [25] and metabolizable energy [24]; and higher milk production, mainly related to higher DMI [30], where you also have higher TDN compared to fodder with lower DDFD [7].

For F2, it is related to harvest maturity (HM) that alters yield, nutrient composition, digestibility and crop silage potential; most changes are associated with core development, which alters the proportion of HM contributed by its various fractions, generally there is a higher proportion of grains and reduced proportions of stem and leaves [펴]. The sugars in the grains are converted into starch and the DM content of the grains increases [르]; a delay in the harvest of the whole plant, produces a 
higher concentration of starch and a low decrease in the concentrations of $\mathrm{CP}, \mathrm{NDF}$, EE and ashes [34,38]. The concentration of $\mathrm{CP}$ is similar among hybrid maize, suggesting that harvest recommendations are based on maturity, and may vary according to the hybrid being grown [39]. The maturity of the whole plant at harvest affects the yield of lactation by dairy cows, the higher the maturity and with an estimate of the nutritional value of the Nitrogen Free Extract, a higher production is achieved when harvested at approximately $35 \mathrm{~g} / 100 \mathrm{~g}$ DM [녀] ]. Ferraretto and Shaver [27] found a decrease in fat corrected milk yield (FCM, 3.5\%) of 2.0 and $2.7 \mathrm{~kg} \mathrm{DM} / \mathrm{cow}$ per day, on average, respectively, when the whole plant was harvested above $40 \mathrm{~g} / 100 \mathrm{~g}$ DM. Therefore, targeting $35 \mathrm{~g} / 100 \mathrm{~g}$ DM at harvest is recommended to optimize the nutritional value of the whole plant and lactation yield in dairy cows [34]].

F3 shows the results of factors F1 and F2, where the harvest closest to grain maturity, within the DM window of 30 to $40 \mathrm{~g} / 100 \mathrm{~g}$ DM will have an adequate starch concentration and DM yield, as well as a higher NDFD and DMI, with energy content of the whole plant [2ㄷ]; Therefore, the optimal cutting time should be monitored to have an increase in yield, but without decreasing its nutritional value [24]; the progressive maturity of the corn harvest during the period of grain filling increases the DM and starch content, and decreases the NDF and CP content [ $\underline{3}]$.

For F4, the NDF concentration normally decreases with maturity due to the dilution effects of increasing starch concentration. Therefore, the high mean NDF concentration is consistent with the low mean starch concentration [2ㄷ]. Delaying harvest time results in higher starch content in corn silage, but compromises the NDF content, particularly the NDFD []ㅡ. DM, CP and lignin contents increased with advanced maturity, but starch and NDF contents did not follow a pattern consistent with hybrid maize [30]. Starch and DM concentrations increased or tended to increase with maturity, while NDF concentrations decreased [29]. F5, ash content is used as an indirect method to estimate losses based on the assumption that as spoilage occurs, OM disappears, but the absolute amount of ash remains constant; ash content in the silage or silage core has small increases related to spoilage that represent percentage increases in the loss of OM [무].

In Table $\underline{6}$, the CL1 "Starch" registered the highest milk production ( $\mathrm{kg}$ of milk/ton/DM ha-1); it was related to a higher concentration of $\mathrm{Mcal} / \mathrm{kg} / \mathrm{DM}$, influenced by its starch concentration, and of NFC, associated to DMY; this association is due to one of the main factors that determine the nutritional quality of silage, which is the NDF content, resulting from the degree of maturity reached

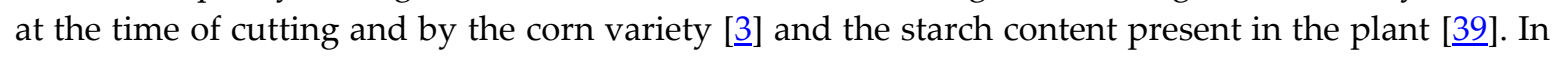
this group we can assume the presence of early hybrid maize, which presents a higher DMD in vitro, compared to intermediate or late cycle hybrids [1ㅣ], likewise, the early plants are smaller, with a higher production of cob and proportion of grain; this characteristic allows having a low NDF content

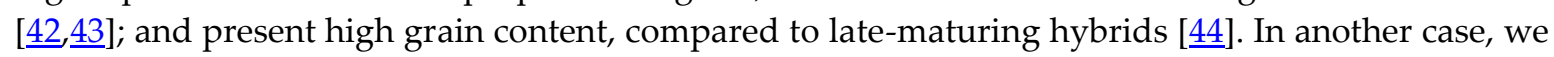
can find maize from temperate climates that present a higher DMD compared to those from tropical climates[느].

Some varieties of corn with a higher lysine content, allow a softer endosperm, generating a higher DMD and starch content []]. Marchesini et al. [1] ] mentioned that a lower NDF content occurs at advanced stages of maturity, resulting in higher grain content and low fiber content; this grain increases the energy value [34], providing a higher amount of starch [ㄴ5], and this presents a dilution effect of the NDF [ $\underline{46}]$, being the grain, the most digestible part of the plant, resulting in a higher DMD in vitro [25]. Higher NDF levels are associated with increased starch content in late harvest; this concentration is a consequence of the transport of sugars from the remains to the cob to be converted into starch [44]. NDFD limits milk production and DMI; having an increase in NDFD content of forage increases, increasing energy content and potentially milk production [ $[\underline{30} \underline{30}$; "an increase of one unit in NDFD content in the diet results in $0.177 \mathrm{~kg}$ per day increase in DMI" [47]; with a higher NDFD, the NDF increases the rumen passage rate and there is an increase in the DMI [25]. Ferraretto et al. [34] found that nutrient digestibility (DM, NDF, OM and starch) was higher for maize with higher leaf content, followed by dual-purpose and brown central rib maize; which presents a higher NDFD in vitro, these digestibilities, may be related to a lower amount of vitreous grain, compared to dual-purpose and brown central rib hybrids. 
For the CL2 "FAT", we can find the late hybrids or tropical regions that tend to produce a greater content of fibers and low digestibility with respect to early genotypes and of temperate regions [프]; as a consequence of higher temperatures, they increase the fiber or lignin deposition, because they increase the rate of plant development and the activity of enzymes that synthesize lignin [19]; in some researches it has been reported that the increase of lignin is a consequence of the lower content of leaves and higher contents of fibers and stems. For Weiss and Wyatt [48], a higher content of EE is presented in corn with a higher content of oil, where we found $5 \mathrm{~g} / 100 \mathrm{~g}$ DM more of lipids than in conventional corn; NutriDense corn, which were developed to produce grains with a great proportion of embryo, and consequently a higher content of lipids, protein and some essential amino acids and the high oleic corn that presents a composition of modified fatty acids, achieving better quality corn oils [ $\underline{30}, \underline{49}]$; by maintaining a higher concentration of EE, a higher content in energy density is observed, compared to carbohydrates [ $\underline{50}]$, presenting a high concentration of $\mathrm{Mcal} / \mathrm{kg} / \mathrm{DM}$ and TDN. A higher concentration of EE generates more energy compared to starch and protein [ $\underline{51}]$.

In the CL3 "Dry Matter", we found a high content of this component, presenting an advanced maturity, where the concentration of $\mathrm{CP}$ was low $[\underline{3}, \underline{29}, \underline{50}, \underline{52}, \underline{53}]$; This level of $\mathrm{CP}$ is attributed to the increase of DM production, caused by the dilution of proteins in DM [54]. Similarly, with increasing maturity, the EE decreases [38]. This is related to the low leaf-stem-maturity ratio, due to more leaves senescing during grain filling []ㅡ. González et al. [ㄷ5] mention that the differences between early and late hybrids may be due to this senescence in the leaves, observed in intermediate basal leaf hybrids with a longer drying time than early ones, increasing the DM; the loss in quantity and quality of leaves by senescence, decreases the nutritional quality [3]. With the advance of maturity, structural carbohydrates increase due to the accumulation of cellulose and lignin [38] and the sugars of the grains are converted into starch and their DM content increases [ㅁ0]; these delays in the harvest of the whole plant, produce a concentration of starch, which increases the NDFD by dilution effect [프]; maize harvested in the early grain-filling period or those genetically modified for low lignin content (brown central rib: BMR), degrade rapidly in the rumen and consequently increase the DMI []]; presenting a higher NDFD compared to dual-purpose maize [56]. Ferraretto and Shaver [27] reported a decrease in milk yield, when the whole plant was harvested above $40 \mathrm{~g} / 100 \mathrm{~g}$ DM; it should be harvested at $35 \mathrm{~g} / 100 \mathrm{~g}$ DM to optimize the nutritional value of the whole plant and the milk yield [34]; it is associated to the exposed endosperm, which is not completely digested due to the existence of zein starch protein, due to the degree of maturity at harvest [39].

The CL4 group "Density of plants ha-1" presented a higher yield of DM ha-1, influenced by the higher density of plants ha-1 [57] indicated that a higher production of $\mathrm{kg}$ of milk/ton/DM is directly related to a higher yield of $\mathrm{DM} \mathrm{ha}^{-1}$ and its contribution at the moment of making the estimations with the MILK2006® program. The higher milk production per hectare is mainly due to the higher dry matter yield, and not to the quality of the forage per se, the NDF and CP contents remained without significant changes [프]

In CL5 "NDF", a lower DM content was observed, which is attributed to a forage harvested before it has reached maturity, resulting in lower DM yields, starch and energy concentrations $[\underline{29}, \underline{44}, \underline{50}]$. NDF values decrease with advancing maturity [느]. It can be attributed to late or tropical hybrids that tend to produce higher NDF content and low NDF [4] ] and their slower grain-filling period is related to high temperatures, which increase the DM to more lignified tissues, causing an increase in DM and lignin content and generating a rapid filling of the cob, in a low concentration of starch, by the affectation of the starch-synthase enzyme that controls starch synthesis [19]. Selection of late-cycle hybrids indicates that selecting for higher stem hardness in corn is used to increase pest and kernel resistance, and results in higher NDF, DAF and lignin content [42]. Higher NDF concentration reduces energy density (Mcal/kg/DM) [58], with NDF content $>55 \mathrm{~g} / 100 \mathrm{~g}$ DM there is a negative correlation with intake and NDF [ $\underline{54}]$; higher moisture concentration is negatively related to DMI [미] .

In the CL6 "Raw Protein", we can find a high content of CP, which can be attributed to the use of anhydrous ammonia or urea as an additive [14], these additions generate a higher content of $\mathrm{CP}$, up to an increase of $95 \mathrm{~g} / 100 \mathrm{~g}$ DM [무]. According to Allen et al. [미] the treatment with urea varies from 6.4 to $16.0 \mathrm{~g} / 100 \mathrm{~g} \mathrm{DM}$, while the application of anhydrous ammonia increases the CP from 
approximately 8 to $12.5 \mathrm{~g} / 100 \mathrm{~g}$ DM [14]. For Rodriguez et al. [으] the use of dehydrated molasses and minerals decreases the OM content, as observed in the results obtained in this LC6. The increase of DM corresponds to a decrease in plant NFC content, since NFC synthesized in flowering phase and stored at stem and leaves level are used to synthesize starch in grains, which mostly contributes to DM increase [1ㅜ].

In Table $\underline{7}$, the correlation between yield of tons of DM and milk production ha $^{-1}$ is significantly influenced by the population density; a high population density increases the production of forage $\left(\mathrm{kg} / \mathrm{DM} \mathrm{ha}^{-1}\right)$ [21]. A higher population density in the short season, presents small corn plants; as the population increases, the maturation and cutting date can be delayed, contributing to a decrease in the EE and starch content and an average concentration of NDF [25]. Higher yield of DM, with a large plant population, leads to higher milk production, due to increased DMI [61].

As for the correlation between DM and NDFD and starch, it is affected by the plant's maturity stage, modifying the starch and NDFD content [29]; NDF and NDFD concentrations of the whole plant were influenced by the maturity stages; NDF content of the whole plant decreased with the maturity stage [46], showing that the DM content ( $>35 \mathrm{~g} / 100 \mathrm{~g} \mathrm{DM})$ mainly causes a decrease in the NDD, while at a very early stage of DM harvest $(<25 \mathrm{~g} / 100 \mathrm{~g} \mathrm{DM})$ there is a relationship between starch and NDFD [3]. The NDF correlations, indicated that a higher NDF content commonly occurs with silage at a very early maturity ( $<25 \mathrm{~g} / 100 \mathrm{~g} \mathrm{DM})$, resulting in a lower starch content [3] and by silageing the material with more moisture, it will generate a low concentration of NFC resulting from filtration in by increased fluid production in the silo and will cause a decrease in the NDFD [25]; including silage will have a low concentration of TND, Mcal $/ \mathrm{kg} / \mathrm{DM}$ and lower DMI, resulting in lower milk yields [3].

NDF was negatively correlated with digestibility [33]; NDF affects DMI and milk production, digestibility has a high impact on milk production; forages with high NDF have higher NDF values [7]; this NDF value was negatively correlated with NDF [51]. The strategy to improve the digestibility of NDF in silage is often related to a reduction in lignin or the concentration of indigestible NDF [31]. NDF content was negatively correlated with NPC [151]; an increase in NCP content decreases NDF content, due to dilution effect [62]. NDFD decreased significantly with increasing DM content in corn silage from "very wet to dry"; however, in parallel to NDFD content, most of this decrease occurred when the DM content increased from very wet to wet [ $\underline{3}$; A high NDFD of the whole plant occurs when it is harvested above $40 \mathrm{~g} / 100 \mathrm{~g} \mathrm{DM}$, related to effects of high digestibility by starch [르] ; these changes reflect the transition from vegetative to reproductive growth in plants [르] . A high NDFD will generate high DMI and metabolizable energy [려], which will have high TDN values []]. The low TDN coefficient indicates its lower contribution to the energy available to cattle, this may be related to the negative effect of NDF, particularly lignocellulose component, on ruminal degradation and total digestibility of the tract [51].

For the correlations given by NFC, Starch, TND and Mcal $/ \mathrm{kg} / \mathrm{DM}$, we can say that a high content of fermentable NFC from good quality corn silage will be in 27 and $32 \mathrm{~g} / 100 \mathrm{~g} \mathrm{DM}$, with high proportion of grain [24]; this is due to the process of starch formation, either by photosynthesis or in the reallocation of water-soluble carbohydrates from the stalk, contributes greatly to the production of storable DM of NFC and starch [ $\underline{3}]$; the concentrations of these components increased linearly with maturity, reflecting the transition from vegetative to reproductive growth in plants [르]. The high milk production observed by maize with high NDFD mainly related to high DMI [30]. Starch is the main source of energy in corn silage and also one of the main sources of fermentable energy in the rumen [3] ; starch is the main carbohydrate in NCF; its presence in the rations is increasingly high given its high energy value and its capacity to stimulate microbial population growth [ㅎ3]; which will have high TDN values [?] and therefore a high Mcal $/ \mathrm{kg} / \mathrm{DM}$.

\section{Conclusions}

In CL1 it was characterized by a higher DMD, NDFD, NFC and starch that allow having a higher TNDx1DM and an energy concentration (Mcal/kg of DM) showing a higher milk production ( $\mathrm{kg}$ of 
milk/ton/DM ha-1). In the same way, the characteristics of CL2 with higher EE content, allow to have a higher TNDx1DM and an energy concentration (Mcal/kg DM) in order to have a higher milk production ( $\mathrm{kg}$ of milk/ton/MS ha- ${ }^{-1}$ ). The concentration of DM increases in the whole plant due to the effect of maturity, affecting the starch content and NDFD; the DM content ( $>35 \mathrm{~g} / 100 \mathrm{~g} \mathrm{DM}$ ) mainly causes a decrease in the NDFD, while in a very early stage of DM harvest $(<25 \mathrm{~g} / 100 \mathrm{~g} \mathrm{DM})$ a low ratio of starch - NDFD is presented. NDF correlations indicate that a higher NDF content is commonly produced with silage at a very early maturity $(<25 \mathrm{~g} / 100 \mathrm{~g} \mathrm{DM})$, resulting in a lower starch content and when silage material with high moisture content will generate a low NFC concentration resulting from silo filtration and will generate a lower NDF; this silage feed will have a low TDN, Mcal $/ \mathrm{kg}$ DM concentration and a lower DMI, resulting in lower milk yields.

Author Contributions: M.G.R. conceived the work and designed the study. Oversight and leadership responsibility for the research activity planning and execution. I.G.-C. conducting investigation process, specifically performing the data collection and wrote the manuscript. MGR, E.M.R.LERJ Formulation and evolution of overarching research goals and aims. Revised the manuscript. MGR, OACO LERJ. IGC. application of statistical techniques to analyze and synthesize study data. MGR, OACO LERJ. IGC. Formulation and evolution of overarching research goals and aims. Revised the manuscript. MGR, OACO LERJ. IGC , EMR management activities to scrub data and maintain research data for initial use and later re-use. Revised the manuscript. MGR, OACO LERJ. IGC. Formulation and evolution of overarching research goals and aims. Revised the manuscript. All authors have read and agreed to the published version of the manuscript.

Funding: Not applicable.

\section{Acknowledgments:}

Conflicts of Interest: The authors declare no conflict of interest.

\section{References}

1. Leonhart, D.; Beneitez, A. Forrajeras cultivadas anuales y perennes más difundidas en la provincia de La Pampa; 9878333078; Ediciones INTA Anguil: 2019; pp 27-32.

2. Fernández Mayer, A. Impacto de los silajes de planta entera (maíz o sorgo) en los sistemas de engorde intensivo (pastoril ya corral). 2014.

3. Khan, N.A.; Yu, P.; Ali, M.; Cone, J.W.; Hendriks, W.H. Nutritive value of maize silage in relation to dairy cow performance and milk quality. J Sci Food Agric 2015, 95, 238-252, doi:10.1002/jsfa.6703.

4. Hidalgo, E.M.; Bustamante, M.B.; Pincay, C.M.; Ubilla, L.D.; Cedeño, C.C. Evaluación de la calidad nutricional de los ensilajes en bolsa de los híbridos de maíz Somma y Trueno aplicando dos aditivos en la zona de Colimes. Espirales revista multidisciplinaria de investigación 2018, 2.

5. Mandic, V.; Bijelic, Z.; Krnjaja, V.; Simic, A.; Petricevic, M.; Micic, N.; Caro-Petrovic, V. Effect of harvesting time on forage yield and quality of maize. Biotechnology in Animal Husbandry 2018, 34, 345-353, doi:10.2298/bah1803345m.

6. $\quad$ Ali, W.; Nadeem, M.; Ashiq, W.; Zaeem, M.; Thomas, R.; Kavanagh, V.; Cheema, M. Forage Yield and Quality Indices of Silage-Corn Following Organic and Inorganic Phosphorus Amendments in Podzol Soil under Boreal Climate. Agronomy 2019, 9, doi:10.3390/agronomy9090489.

7. Combs, D. Forage quality and utilization: total tract NDF digestibility. In Proceedings of Proceedings, Western States Alfalfa and Forage Symposium, Reno, NV; pp. 2-4. 
8. Rivas, J.M.A.; Carballo, C.A.; Quero, C.A.R.; Hernández, G.A.; Vaquera, H.H.; Rivas, Z.E.C.; Rivas, Z.M.A.; Rivas, Z.E.J. Comportamiento productivo de doce híbridos trilineales de maíz para forraje en una región tropical seca. Tropical and Subtropical Agroecosystems 2018, 21, 579-586.

9. Sánchez Hernández, M.Á.; Cruz Vázquez, M.; Sánchez Hernández, C.; Morales Terán, G.; Rivas Jacobo, M.A.; Villanueva Verduzco, C. Rendimiento forrajero de maíces adaptados al trópico húmedo de México. Revista mexicana de ciencias agrícolas 2019, 10, 699-712.

10. Bertoia, L.M. algunos conceptos sobre el cultivo de maíz para ensilaje. Facultad deficiencias agrarias. Sitio argentino de Producción Animal 2015.

11. Zaragoza-Esparza, J.; Tadeo-Robledo, M.; Espinosa-Calderón, A.; López-López, C.; García-Espinosa, J.C.; Zamudio-González, B.; Turrent-Fernández, A.; Rosado-Núñez, F. Rendimiento y calidad de forraje de híbridos de maíz en Valles Altos de México. Revista mexicana de ciencias agrícolas 2019, 10, 101 111.

12. Sánchez-Ledezma, W.; Hidalgo-Ardón, C. Potencial forrajero de nueve híbridos de maíz en la zona alta lechera de Costa Rica. Agronomía Mesoamericana 2018, 29, doi:10.15517/ma.v29i1.27732.

13. Nair, J.; Xu, S.; Smiley, B.; Yang, H.E.; McAllister, T.A.; Wang, Y. Effects of inoculation of corn silage with Lactobacillus spp. or Saccharomyces cerevisiae alone or in combination on silage fermentation characteristics, nutrient digestibility, and growth performance of growing beef cattle. J Anim Sci 2019, 97, 4974-4986, doi:10.1093/jas/skz333.

14. Yitbarek, M.B.; Tamir, B. Silage Additives: Review. Open Journal of Applied Sciences 2014, 04, 258-274, doi:10.4236/ojapps.2014.45026.

15. Shaver, R. Corn silage evaluation: The MILK2006 update. In Proceedings of Proc. 41st Pacific Northwest Anim. Nutr. Conf. Vancouver, Canada; pp. 71-80.

16. NRC, I. Nutrient requirements of dairy cattle. National Research Council 2001.

17. SAS, S. User's Guide: Statistical Analysis System. SAS Institute, Cary, NC, USA: 2007.

18. Santana, R.F.; Granillo, M.R.; Espinoza, S.F.I.; Aguilar, O.J.C.; Ortega, Z.J.G. Caracterización de la cadena de valor del maíz. Ingenio y Conciencia Boletín Científico de la Escuela Superior Ciudad Sahagún 2018, 5 .

19. Bernardes, T.F.; Daniel, J.L.P.; Adesogan, A.T.; McAllister, T.A.; Drouin, P.; Nussio, L.G.; Huhtanen, P.; Tremblay, G.F.; Belanger, G.; Cai, Y. Silage review: Unique challenges of silages made in hot and cold regions. J Dairy Sci 2018, 101, 4001-4019, doi:10.3168/jds.2017-13703.

20. Guerrero, J.E.L.; Rojas, A.F.V.; Cortés, M.M.A.; Fernández, L.F.C. Panorama general de los organismos genéticamente modificados en Colombia y en el mundo: Capacidad nacional de detección. Revista Colombiana de Biotecnología 2018, 20, 101-116.

21. Guacapiña, A.; Rodríguez, L.F.; Godoy, A. Evaluación de la variedad de maíz (Zea mays L.) INIAP180, para la elaboración de ensilaje. 2018.

22. Camarasa, J.N.; Barletta, P.F.; Larrosa, F. Rendimiento de forraje y calidad nutricional con densidades bajas de maíz para ensilaje; 2469-164X; Ediciones INTA: 2019.

23. Calsamiglia, S.; Ferret, A.; Bach, A. Tablas FEDNA de valor nutritivo de Forrajes y Subproductos fibrosos húmedos. Fundación para el desarrollo de la Nutrición Animal. Madrid 2004, 1. 
24. Vanegas, R.J.L.; Codero-Ahiman, O.V. Ensilaje como fuente alterna de alimentación del ganado de bovino en la producción lechera. Revista Ecuatoriana de Ciencia Animal 2019, 3, 129-162.

25. Guyader, J.; Baron, V.; Beauchemin, K. Corn Forage Yield and Quality for Silage in Short Growing Season Areas of the Canadian Prairies. Agronomy 2018, 8, doi:10.3390/agronomy8090164.

26. Cardozo, J.V. El matarratón (Gliricidia sepium) en la alimentación de rumiantes. 2013.

27. Ferraretto, L.F.; Shaver, R.D. Meta-analysis: Effect of corn silage harvest practices on intake, digestion, and milk production by dairy cows. The Professional Animal Scientist 2012, 28, 141-149, doi:10.15232/s1080-7446(15)30334-x.

28. Chaudhary, D.P.; Jat, S.L.; Kumar, R.; Kumar, A.; Kumar, B. Fodder Quality of Maize: Its Preservation. In Maize: Nutrition Dynamics and Novel Uses, 2014; 10.1007/978-81-322-1623-0_13pp. 153-160.

29. Arriola, K.G.; Kim, S.C.; Huisden, C.M.; Adesogan, A.T. Stay-green ranking and maturity of corn hybrids: 1. Effects on dry matter yield, nutritional value, fermentation characteristics, and aerobic stability of silage hybrids in Florida. J Dairy Sci 2012, 95, 964-974, doi:10.3168/jds.2011-4524.

30. Ferraretto, L.F.; Shaver, R.D. Effects of whole-plant corn silage hybrid type on intake, digestion, ruminal fermentation, and lactation performance by dairy cows through a meta-analysis. Journal of Dairy Science 2015, 98, 2662-2675, doi:10.3168/jds.2014-9045.

31. Grant, R.J.; Ferraretto, L.F. Silage review: Silage feeding management: Silage characteristics and dairy cow feeding behavior. J Dairy Sci 2018, 101, 4111-4121, doi:10.3168/jds.2017-13729.

32. Martínez, T.; Daniela, A. Evaluación nutricional del ensilaje de maíz cosechado en cuatro etapas fenológicas elaborado con tres calibres de picado. 2017.

33. Salama, H.S.A. Yield and nutritive value of maize (Zea mays L.) forage as affected by plant density, sowing date and age at harvest. Italian Journal of Agronomy 2019, 14, 114-122, doi:10.4081/ija.2019.1383.

34. Ferraretto, L.F.; Shaver, R.D.; Luck, B.D. Silage review: Recent advances and future technologies for whole-plant and fractionated corn silage harvesting. J Dairy Sci 2018, 101, 3937-3951, doi:10.3168/jds.2017-13728.

35. Nestor Jr, K. Silage quality: how is it defined and measured?. 2010.

36. NRC, i. Nutrient requirements of dairy cattle (Update, 1989). Natl. Acad. Sci., Washington, DC 1988.

37. Ferraretto, L.F.; Shaver, R.D. Effect of Corn Shredlage on lactation performance and total tract starch digestibility by dairy cows. The Professional Animal Scientist 2012, 28, 639-647, doi:10.15232/s10807446(15)30423-x.

38. Amodu, J.T.; Akpensuen, T.T.; Dung, D.D.; Tanko, R.J.; Musa, A.; Abubakar, S.A.; Hassan, M.R.; Jegede, J.O.; Sani, I. Evaluation of Maize Accessions for Nutrients Composition, Forage and Silage Yields. Journal of Agricultural Science 2014, 6, doi:10.5539/jas.v6n4p178.

39. Ferraretto, L.F.; Shaver, R.D.; Massie, S.; Singo, R.; Taysom, D.M.; Brouillette, J.P. Effect of ensiling time and hybrid type on fermentation profile, nitrogen fractions, and ruminal in vitro starch and neutral detergent fiber digestibility in whole-plant corn silage. The Professional Animal Scientist 2015, 31, 146152, doi:10.15232/pas.2014-01371.

40. Borreani, G.; Tabacco, E.; Schmidt, R.J.; Holmes, B.J.; Muck, R.E. Silage review: Factors affecting dry matter and quality losses in silages. J Dairy Sci 2018, 101, 3952-3979, doi:10.3168/jds.2017-13837. 
41. Marchesini, G.; Serva, L.; Chinello, M.; Gazziero, M.; Tenti, S.; Mirisola, M.; Garbin, E.; Contiero, B.; Grandis, D.; Andrighetto, I. Effect of maturity stage at harvest on the ensilability of maize hybrids in the early and late FAO classes, grown in areas differing in yield potential. Grass and Forage Science 2019, 10.1111/gfs.12438.

42. Nuñez, H.G.; Faz, C.R.; Tovar, G.M.d.R.; Zavala, G.A. Híbridos de maíz para la producción de forraje con alta digestibilidad en el norte de México. Técnica Pecuaria en México 2001, 39, 77-88.

43. Peña, R.A.; Nuñez, H.G.; González, C.F. Potencial forrajero de poblaciones de maíz y relación entre atributos agronómicos con la calidad. Revista Mexicana de Ciencias Pecuarias 2002, 40.

44. Lynch, J.P.; O'Kiely, P.; Doyle, E.M. Yield, quality and ensilage characteristics of whole-crop maize and of the cob and stover components: harvest date and hybrid effects. Grass and Forage Science 2012, 67, 472-487, doi:10.1111/j.1365-2494.2012.00868.x.

45. Depetris, G.J. Valor nutricional del grano y ensilaje de maíz en la alimentación de bovinos para carne. In Proceedings of Jornada de Actualización. Calidad del grano de maíz para la industria y la producción en bovinos (Balcarce, 15 de Noviembre de 2013).

46. Souza Filho, A.X.; Von Pinho, R.G.; Resende Pereira, J.L.d.A.; Costa dos Reis, M.; Vilela de Rezende, A.; Diego de Castro, M. Influence of stage of maturity on bromatological quality of corn forage. Revista Brasileira de Zootecnia 2011, 40, 1894-1901, doi:10.1590/s1516-35982011000900008.

47. Hoffman, P.; Combs, D.; Contreras-Govea, F.E.; Neutro, D. Uso de la digestibilidad del FDN en la Formulación de Raciones. Focus Forage 2004, 6, 1-5.

48. Weiss, W.; Wyatt, D. Effect of oil content and kernel processing of corn silage on digestibility and milk production by dairy cows. Journal of dairy science 2000, 83, 351-358.

49. De León, M.; Bulaschevich, M.C.; Boetto, C.; Gonzalez Palau, C.; Peuser, R.; Cabanillas, A. Efecto del genotipo de maíz sobre la desaparición ruminal de materia seca en silajes de planta entera. In Proceedings of Congreso Argentino de Producción Animal. 34. Joint Meeting ASAS-AAPA. 1. 201110 04-07, 4-7 de octubre de 2011. Mar del Plata, Buenos Aires. AR.

50. Allen, M.S.; Coors, J.G.; Roth, G.W. Corn silage. Silage science and technology 2003, 42, 547-608.

51. Jayanegara, A.; Ridla, M.; Laconi, E. Estimation and validation of total digestible nutrient values of forage and concentrate feedstuffs. In Proceedings of IOP Conference Series: Materials Science and Engineering; p. 042016.

52. Jiménez-Leyva, D.; Romo-Rubio, J.; Flores-Aguirre, L.; Ortiz-López, B.; Barajas-Cruz, R. Edad de corte en la composición química del ensilado de maíz blanco asgrow-7573. Abanico veterinario 2016, 6, 1323.

53. Row, C.A. Corn plant maturity effect on yield and nutritional quality; corn silage inoculation on performance of cattle fed silage with or without live yeast added. 2015.

54. Henrique, V.H.; Vilela de, R.A.; Paulo de Figueiredo, V.; Augusto, A., Gustavo; Ricardo, E.A.; Benedito de Souza, A.G. Valor nutritivo de silagens de milho colhido em diversos estádios de maturação. Revista Brasileira de Zootecnia 2008, 37, 1192-1199.

55. González Castañeda, F.; Núñez Hernández, G.; Peña Ramos, A. Etapas de corte, producción y calidad forrajera de híbridos de maíz de diferente ciclo biológico. Revista Fitotecnia Mexicana 2006. 
56. Der Bedrosian, M.C.; Nestor, K.E., Jr.; Kung, L., Jr. The effects of hybrid, maturity, and length of storage on the composition and nutritive value of corn silage. J Dairy Sci 2012, 95, 5115-5126, doi:10.3168/jds.2011-4833.

57. Cañadas, Á.; Molina, C.; Rade, D.; Fernández, F. Interacción época/densidad de siembra sobre la producción de ocho híbridos de maíz forrajeros, Ecuador. Revista MVZ Córdoba 2016, 21.

58. Bal, M.; Coors, J.; Shaver, R. Impact of the maturity of corn for use as silage in the diets of dairy cows on intake, digestion, and milk production. Journal of Dairy Science 1997, 80, 2497-2503.

59. Demirel, M.; Yilmaz, İ.; Deniz, S.; Kaplan, O.; Akdeniz, H. Effect of Addition of Urea or Urea Plus Molasses to Different Corn Silages Harvested at Dough Stage on Silage Quality and Digestible Dry Matter Yield. Journal of Applied Animal Research 2003, 24, 7-16, doi:10.1080/09712119.2003.9706429.

60. Rodríguez-Chacón, S.; López-Herrera, M.; WingChing-Jones, R.; Rojas-Bourrillón, A. Adición de melaza deshidratada y urea en ensilados de rastrojos de piña. Agronomía Mesoamericana 2014, 25, 312321.

61. Ballard, C.; Thomas, E.; Tsang, D.; Mandebvu, P.; Sniffen, C.; Endres, M.I.; Carter, M. Effect of corn silage hybrid on dry matter yield, nutrient composition, in vitro digestion, intake by dairy heifers, and milk production by dairy cows. Journal of dairy science 2001, 84, 442-452.

62. Genero, G.A. Efecto del ensilaje de maíz nervadura marrón sobre la respuesta productiva de vacas lecheras en estabulación y parámetros de fermentación in vitro. Universidad Nacional de Mar del Plata, 2015.

63. Garrido, A.G. Los carbohidratos en la alimentación de la vaca de leche. Frisona española 2014, 34, 106109. 